Article

\title{
Technoeconomic Assessment of Hybrid Organosolv-Steam Explosion Pretreatment of Woody Biomass
}

\author{
Sennai Mesfun ${ }^{1}\left(\mathbb{D}\right.$, Leonidas Matsakas ${ }^{2}\left(\mathbb{D}\right.$, Ulrika Rova $^{2}\left(\mathbb{D}\right.$ and Paul Christakopoulos ${ }^{2, *}$ \\ 1 RISE Research Institute of Sweden, P.O. Box 5604, 11486 Stockholm, Sweden; Sennai.asmelash.mesfun@ri.se \\ 2 Biochemical Process Engineering, Division of Chemical Engineering, Department of Civil, Environmental \\ and Natural Resources Engineering, Luleå University of Technology, 97187 Luleå, Sweden; \\ leonidas.matsakas@ltu.se (L.M.); ulrika.rova@ltu.se (U.R.) \\ * Correspondence: paul.christakopoulos@ltu.se; Tel.: +46-(0)920-492-510
}

Received: 3 October 2019; Accepted: 29 October 2019; Published: 4 November 2019

check for updates

\begin{abstract}
This study investigates technoeconomic performance of standalone biorefinery concepts that utilize hybrid organic solvent and steam explosion pretreatment technique. The assessments were made based on a mathematical process model developed in UniSim Design software using inhouse experimental data. The work was motivated by successful experimental applications of the hybrid pretreatment technique on lignocellulosic feedstocks that demonstrated high fractionation efficiency into a cellulose-rich, a hemicellulose-rich and lignin streams. For the biorefinery concepts studied here, the targeted final products were ethanol, organosolv lignin and hemicellulose syrup. Minimum ethanol selling price (MESP) and Internal rate of return (IRR) were evaluated as economic indicators of the investigated biorefinery concepts. Depending on the configuration, and allocating all costs to ethanol, MESP in the range $0.53-0.95 € / \mathrm{L}$ were required for the biorefinery concepts to break even. Under the assumed ethanol reference price of $0.55 € / L$, the corresponding IRR were found to be in the range $-1.75-10.7 \%$. Hemicellulose degradation and high steam demand identified as major sources of inefficiencies for the process and economic performance, respectively. Sensitivity of MESP and IRR towards the most influential technical, economic and market parameters performed.
\end{abstract}

Keywords: organosovl; steam explosion; technoeconomic; biorefinery; ethanol; lignin; pretreatment; biofuels

\section{Introduction}

The transition from fossil-based economy into bio-based economy is high on the agenda both at the national and international levels. As a low-carbon energy resource and a carbon management mechanism, biomass is expected to play essential role in the transformation of energy sector under stringent climate change mitigation accords. Sweden is endowed with forestry that can potentially provide sustainable source of biomass for bioenergy production. Lignocellulosic biomass has a great potential to be utilized as bioenergy feedstock due to the high volume of residues generated from the production of pulp and timber, which derives during harvesting and thinning of trees onsite as well as during debarking and sawing at the production facilities. In the case of Sweden, efficient utilization of lignocellulosic wood is crucial to channel the vast feedstock potential for enabling impactful transition. A resource-efficient way of converting lignocellulosic biomass to fuels and chemicals is through fractionation into biomass basic components, namely cellulose, hemicellulose, and lignin. These components can separately be converted to fuels, chemicals, and materials through different thermo-chemical and biochemical processes. The thermo-chemical path essentially involves high-temperature conversion step, such as gasification, e.g., References [1,2], pyrolysis, 
e.g., References [3-5], and hydrothermal liquefaction, e.g., References [6,7], which often are followed by chemical synthesis step to reach the desired final products. The biochemical route is rather based on fractionation of the feedstock under mild conditions to produce cellulosic materials, biofuels and chemicals, e.g., References [8-13]. Such a process falls well within the biorefinery concept, which effectively simulates a traditional refinery, in which all the major components of biomass are converted to different products and energy. Use of plant biomass in a biorefinery concept has already shown great potentials from energy potentials point of view and is an environmentally friendly approach, significantly reducing greenhouse gas emissions when replacing fossil diesel with biofuels [14].

Regardless of the vast research focus on harnessing renewable energy for transport, such as electricity and hydrogen, the market penetration of these technologies has been somewhat slow, nor are these options directly applicable to the present road transportation fleet and distribution system. Even under the best-case scenario for deployment of electricity road fleet, achieving fossil free road transportation in Sweden by 2045 is expected to derive largely from biomass. Besides, many countries are enacting mandates for sustainable aviation fuel. Mandated switch from fossil aviation fuel to a sustainable equivalent adds to the competition for feedstock. Therefore, effective fractionation and utilization of all wood components are very important steps to ensure economic viability of new technologies and to minimize competition for feedstock.

Lignin, about $20-33 \%$ wt. of the dry content of lignocellulosic wood, is a typical example of underutilized resource. For instance, kraft pulping produces lignin as byproduct which often is combusted to generate the steam and power required to drive the process. In the context of biorefinery, a switch from lignin as a low-value material to a source to produce value-added chemicals and biomaterials is imperative. The recovery of high-purity lignin opens wide range of application areas from thermoplastic to biooils, e.g., References [15-17]. One approach to obtain high-purity lignin is to recover it early in the process, prior to further processing of the carbohydrate fractions. This emphasizes the need to develop fractionation processes that are capable to produce distinct streams of cellulose, hemicellulose, and lignin, allowing to develop a wide portfolio of fuels, chemicals, and biomaterials that can be produced from biomass.

In this context, organosolv pretreatment/fractionation is regarded as one of the most promising methods for biomass fractionation, capable of producing relatively clean streams of cellulose, hemicellulose, and lignin. It involves the treatment of lignocellulosic biomass with organic solvents for fractionation of biomass into distinct streams at temperatures from 160 to $210^{\circ} \mathrm{C}$. During the process, solvents effectively solubilizes lignin and hemicellulose from the lignocellulosic biomass, which are separated in a form of liquor. Organosolv pretreatment process covers a broad range of organic solvents such as alcohols, organic acids and ketones. The organosolv fractionation generates a cellulose pulp that is highly susceptible to enzymatic hydrolysis and almost free of lignin, an aqueous liquid stream that contains the solubilized hemicellulosic sugars and other derivatives (i.e., furfural), and finally a solid stream of lignin. The lignin produced in this way is of high purity with very low sugar contaminants and most importantly has low ash content, is sulphur-free, and by maintaining a chemical structure close to the natural one $[8,18]$.

Due to the high fractionation efficiency of organosolv pretreatment, the authors previously investigated its application on forest biomass $[8,11,18]$. More specifically, a hybrid pretreatment and fractionation method was developed. The hybrid process combines the fractionation efficiency of conventional organosolv pretreatment and physical size reduction of the feedstock by steam explosion as a result of the sudden pressure drop. To achieve this, an explosive discharge step like in the steam explosion pretreatment process at the end of traditional organosolv cooking, effectively merging organosolv and steam explosion processes into a single-step process. This novel hybrid method was successfully applied for the pretreatment and fractionation of birch and spruce woodchips $[8,18]$.

To emphasize the performance of novel process step for converting biomass, systemic mapping of a value chain utilizing the service of the technology in a biorefinery setup is relevant. Such assessment 
also enables comparison to other pathways of achieving the same service, for example many variants of pretreating lignocellulosic biomass are available such as organosolv, diluted acid, hot water, ammonia fiber explosion $[10,19]$. This study is motivated by the experimental outcomes of a hybrid organic solvent-steam explosion fractionation of lignocellulosic biomass to a cellulose-rich, a hemicellulose-rich and lignin streams, and aims to investigate the performance of this novel technique in a biorefinery setup.

\section{Framework for Assessment}

Design of biorefinery is stepwise process that combines, among other things, selecting high product throughput, exploring product market potential, valorizing side-streams to increase revenue, minimizing environmental impact and optimizing production cost. Given the nature of the study, i.e., investigation of the performance a novel pretreatment technique, ethanol was chosen as target product. Bioethanol is widely accepted bulk chemical used as feedstock for production specialty chemicals such as ethylene, with a global annual market of $130 \mathrm{Mt}$ [20], as drop-in fuel for road transport and most recently as feedstock for aviation fuel production. Besides, lignocellulosic ethanol has been the subject to many researchers establishing very good literature basis to benchmark the outcomes of this study.

Another major product of the biorefinery concepts is high-purity lignin. Although the market for lignin as bio-material is under development, organosolv lignin has purity advantage (compared to, e.g., kraft lignin and lignosulfonate) in areas such as bio-based binding agent and thermoplastic compounds [20]. The following subsections present description of the major process units of the biorefinery concept investigated.

\subsection{Feedstock Composition}

The hybrid fractionation/pretreatment process was applied to both hardwood and softwood and the results were used as basis for the modelling activities in this study $[8,18]$. Birch woodchips with dry \% wt. composition of 34.7 cellulose, 31.2 hemicellulose, 18.7 lignin, 15.4 extractives and ash and spruce woodchips 37.6 cellulose, 17.6 hemicellulose, 32.6 lignin and 12.2 others were used in the experimental campaigns.

\subsubsection{Hybrid Organosolv-Steam Explosion Pretreatment}

Birchwood with moisture content of $6 \%$ wt., ground to about $1 \mathrm{~mm}$ in size, was wetted using ethanol and fed to the pretreatment reactor. Most of the ethanol, more than $90 \%$, is pumped directly into the reactor where saturated steam at $3 \mathrm{MPa}$ was added both to raise the temperature and to maintain a $60 \% v / v$ ethanol-to-water solution inside the reactor. The reactor was operated at $200{ }^{\circ} \mathrm{C}$ with a holding time of $15 \mathrm{~min}$ once the operational temperature was reached. Inside the reactor the process was catalyzed using sulphuric acid with a concentration of $1 \% w / w$ of dry biomass. The target liquid-to-solid ratio (LSR) is to achieve a value below 10, which is important for steam economy. Following the pretreatment process the pretreated stream was discharged to an atmospheric cyclone separator and, in a subsequent stage, a cellulose-rich stream containing about $83 \%$ wt. of the cellulose in the initial feedstock was filtered-out. The stream left behind was an aqueous stream rich in hemicellulose and lignin. The cellulose-rich stream also contains about $11 \%$ and $14 \% \mathrm{wt}$. of the hemicellulose and the lignin in the initial feedstock, respectively. After separation of the cellulose-rich solids, the solvent was recovered using a mechanical vapor recompression evaporator. The hemicellulose and lignin-rich stream is passed through a centrifuge to separate solid-rich lignin stream, containing approx. $98 \% \mathrm{wt}$. lignin dry basis, from the aqueous solution. The aqueous stream can be concentrated to high sugar content molasses, which are present in the form monomers (such as xylose) and soluble oligomers (such as xylobiose).

Spruce with moisture content of $6.23 \%$ wt., ground to about $1 \mathrm{~mm}$ particle size, undergo same pretreatment procedure as described in the case of hardwood with a holding time and ethanol-to-water ratio inside the reactor of $30 \mathrm{~min}$ and $52 \% v / v$, respectively. The cellulose-rich stream in the case of 
spruce contained about $84 \%$ wt. of the cellulose, $10 \%$ wt. of the hemicellulose and $21 \%$ wt. of the lignin in the initial feedstock. The extracted organosolv lignin for spruce was composed of $95 \% \mathrm{wt}$. lignin on dry basis. The concentration of hemicellulosic sugars in the aqueous solution for hardwood is about two times higher compare to that of softwood.

\subsubsection{Liquefaction and Simultaneous Saccharification and Fermentation}

The cellulose-rich pretreated solids were subjected to saccharification under high-gravity conditions. More specifically, pretreated birch solids were adjusted to a solid content of $20 \% w / w$ in $50 \mathrm{mM}$ citrate buffer (ph 5). The enzyme used was Cellic ${ }^{\circledR}$ CTec2 (Novozymes A/S, Bagsværd, Denmark) with total enzyme solution loading rate of $125 \mathrm{~g} / \mathrm{kg}$ solids, i.e., $25 \mathrm{~g}$ per $\mathrm{kg}$ of the slurry. Saccharification took place at $50{ }^{\circ} \mathrm{C}$ for $8 \mathrm{~h}$. Then the temperature was reduced to $35^{\circ} \mathrm{C}$ for the fermentation with the yeast. In the fermentation broth $1 \mathrm{~g} / \mathrm{L}$ yeast extract, $0.5 \mathrm{~g} / \mathrm{L}\left(\mathrm{NH}_{4}\right)_{2} \mathrm{HPO}_{4}, 0.025 \mathrm{~g} / \mathrm{L} \mathrm{MgSO} 4.7 \mathrm{H}_{2} \mathrm{O}$ was added and the initial yeast was $1 \mathrm{~g} / \mathrm{L}$. The final ethanol concentration in the broth, after $168 \mathrm{~h}$, was $80 \mathrm{~g} / \mathrm{L}$ [18].

For spruce, the pretreated solids were adjusted to a solid content of $22 \% w / w$ for saccharification in the same buffer as in the case of birch. Enzyme load was the same, resulting in $27.5 \mathrm{~g}$ per $\mathrm{kg}$ slurry. The same saccharification conditions and nutrients were applied. The final ethanol concentration was $61.7 \mathrm{~g} / \mathrm{L}$ [8].

\subsubsection{Product Recovery}

Ethanol recovery is carried out in a multiple-column setup. The fermentation broth, at this stage most of the solids removed, containing mostly water and traces of volatiles such as $\mathrm{CO}_{2}$ needs to be purified to $99.5 \% w / w$ ethanol. The recovery process is composed of a beer column, a rectifier, a stripper, a distillation column, and a recovery unit for the entrainer. The fermentation broth is fed to the beer column with 30 trays and a reboiler pressure of $0.14 \mathrm{MPa}$, with pressure drop of $0.001 \mathrm{MPa} / \mathrm{stage}$. Ethanol-rich stream, $90 \% w / w$, is recovered at the top and sent to the rectification column, containing 40 trays and has same reboiler pressure and pressure-drop per stage as the beer column. Volatiles, mostly $\mathrm{CO}_{2}$, containing vapor phase ethanol and water are vented at the top and sent to stripping column to recover the ethanol using water as stripping medium. The liquid product from the stripper is distilled separately to increase its ethanol concentration to about $70 \% w / w$ before being sent to the rectification column. Glycerol entrainer is supplied to the 1-stage to facilitate the purification to $99.5 \% w / w$ ethanol in the rectification column. Glycerol is recovered at $100 \% w / w$ in a separate column, containing 10 trays with a reboiler pressure $0.15 \mathrm{MPa}$ and pressure-drop $0.05 \mathrm{MPa} / \mathrm{stage}$, and recycled back to the rectification column after being cooled to about $40^{\circ} \mathrm{C}$.

\subsubsection{Combined Heat and Power (CHP) System}

A dedicated CHP system was considered for supplying the utility requirements of the conceptual process envisioned in this work. There are several reasons for doing so. First, the hybrid organosolv-steam explosion pretreatment process utilizes steam, which was directly supplied to the reactor, thermally (to maintain the reactor temperature at the desired level) and chemically (to facilitate disintegration of the biomass into its components). Hence, all the water added to the reactor to reach the targeted liquid-to-solid ratio (assumed LSR of 10), must be in the form of steam. This results in a significant amount of steam demand. Supplying steam to a standalone operation of such steam-intensive process externally can be logistically challenging.

Second, the biorefinery concept's convert part of the organic substance in the feedstock to final products such as ethanol, lignin and pentose monomers. Thus, considerable part of the organic content of the original feedstock end-up in the fermentation and purification stillage. The stillage, after screening and drying, presents opportunity that can be utilized to fuel a steam boiler that generates part of the steam required in the process at high pressure. Falling bark and forest residues are used to balance fuel deficit to the steam boiler. 
Third, increase the products portfolio. By introducing a back-pressure turbine and an electric generator, the high-pressure steam (HPS) is used to generate electricity as it expands to the pressure levels required in the process, i.e., intermediate pressure steam (IPS) 3-3.5 MPa for the pretreatment reactor and low-pressure steam (LPS) $0.4-0.7 \mathrm{MPa}$ for the product upgrading section. The electricity produced was partly used to drive unit processes and equipment, and the surplus was sold to the grid generating additional revenue.

The CHP system was sized such that the HPS generated in the boiler of the CHP system was matched to the total steam demand of the biorefinery. The HPS was generated at a maximum steam pressure and temperature of $120 \mathrm{bar}$ and $520^{\circ} \mathrm{C}$. High-level assessment approach was assumed when evaluating the steam demand of the biorefinery concepts, i.e., only the major steam consumers such as the pretreatment reactor (IPS) and product upgrading (LPS) were considered. LPS may also be used to augment solvent recovery and concentration of the hemicellulose sugars processes in case the feed stream to the evaporators require preheating. Heating loads for streams below the temperature of $85^{\circ} \mathrm{C}$ were assumed to be satisfied via heat exchangers network with other process streams that require cooling.

\subsubsection{Process Simulation}

The biorefinery concepts simulated are based on woody-biomass feedstock derived from the processing of soft- and hardwood. To derive mass and energy balance a flowsheet of the biorefinery concept was simulated in UniSim Design R460.1 developed by Honeywell. The plant was assumed to be in Sweden, with annual operational time of $7881 \mathrm{~h}$, corresponding to 355 days with an availability of $92.5 \%$. The thermodynamic model non-random two liquids (NRTL) was applied. The target production capacity was set to 50 ktons of dry lignin per year. Figure 1 presents systemic overview of the simulated process.

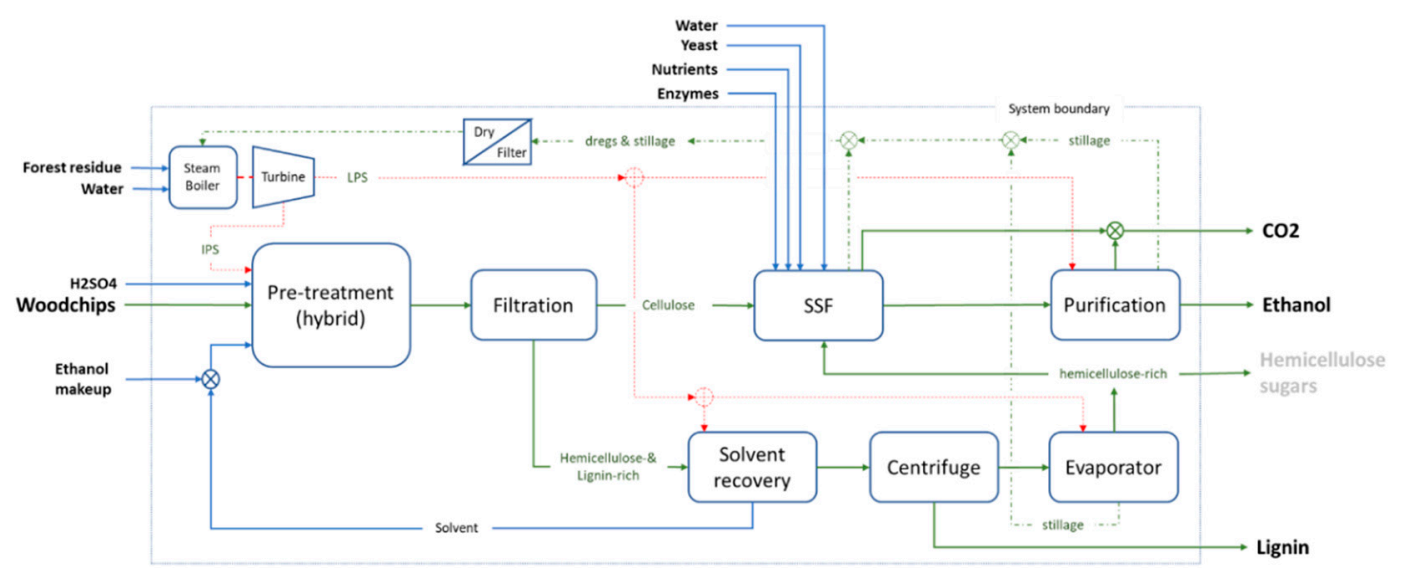

Figure 1. Process flow diagram and system boundary of the biorefinery concept. IPS: intermediate pressure steam; LPS: low-pressure steam; SSF: simultaneous saccharification and fermentation.

The hybrid organosolv-steam explosion process fractionates woody biomass into cellulose-rich, hemicellulose-rich and lignin. Sawdust or chipped wood was mixed with ethanol in a solvent to dry biomass ratio of $6: 1$ for hardwood and 5:1 for softwood. The reactor was heated to $200{ }^{\circ} \mathrm{C}$ by addition of saturated steam at $3 \mathrm{MPa}$ to achieve ethanol concentration of $60 \% v / v$ and $52 \% v / v$ for hardwood and softwood, respectively.

The solvent recovery and the evaporator for concentrating hemicellulose sugars are simulated as mechanical vapor recompression (MVR) evaporators. The incoming streams were flashed to $0.06 \mathrm{MPa}$ and the vapor generated was recompressed to $0.1 \mathrm{MPa}$ and used as heat source to the evaporation units.

As shown in Figure 1, the hybrid pretreatment produces a stream containing hemicellulosic sugars and, to a much lesser extent, C6- sugars resulted from the dissolution of hemicellulose and 
cellulose, respectively. Depending on how this stream was treated, two process configurations for each type of wood were evaluated. The two alternatives were either to concentrate the hemicellulose-rich stream into a hemicellulose syrup final product or co-ferment it to increase ethanol yield. The process configurations and their acronyms (used hereafter) are as follows:

- HWBF (hardwood biomass fractionation): pretreated hardwood solids and hemicellulose sugars converted to ethanol.

- HWBFX (hardwood biomass fractionation with hemicellulose extraction): pretreated hardwood solids converted to ethanol and hemicellulose sugars marketed.

- SWBF (softwood biomass fractionation): pretreated softwood solids and hemicellulose sugars converted to ethanol.

- SWBFX (softwood biomass fractionation with hemicellulose extraction): pretreated softwood solids converted to ethanol and hemicellulose sugars marketed.

\subsection{Economic Analysis}

The economic assessment was performed using the equipment inventory of the process flowsheet developed in UniSim Design. Accordingly, the major process units were sized based on the mass and energy balance derived from the developed flowsheet, Figure A1.

The total fixed capital investment (TFCI) was calculated according to the factorial method proposed by Sinnott and Towler [21]. The purchased equipment cost (PEC) was evaluated using equipment cost correlations outlined by Woods [22]. To this end, correction factors to adjust for fluid-solid processes were applied. In addition, factors that account for installation and erecting ( $60 \%$ of PEC), piping $(50 \%)$, instrumentation and control (60\%), electrical $(20 \%)$, civil works (30\%), structure and buildings $(20 \%)$, lagging and paint $(10 \%)$ were applied when estimating the inside battery limit (ISBL) cost. To calculate the TFCI, outside battery limit (OSBL) cost was added to the estimated ISBL cost by applying factors that account for design and engineering (30\% of ISBL) and contingency (10\%). PEC values were updated to 2014 using chemical engineering plant cost index (CEPCI) of 576. All monetary values reported refer to Euro value of the year 2014.

To compute the production cost of ethanol, fixed and variable operating costs were calculated using the data presented in Table 1. The plant was assumed to be operational 355 days with an availability of $92.5 \%$, corresponds to 7881 operational hours per year.

To determine the profitability of the biorefinery concepts minimum ethanol selling price (MESP) was evaluated as an economic indicator. The production of ethanol reaches full-scale after three years by assuming $30 \%$ and $70 \%$ of the full capacity for Year 1 and Year 2, respectively. The MESP was calculated using a discounted cash flow model. A discount rate of $10 \%$ was used for the basecase (Table 2). For the investment, loan to equity ratio of 4 and loan interest rate of $4 \%$ was applied. A working capital equivalent to 5\% TFCI was added. The economic lifetime of the plant was set to 30 years. 
Table 1. Economic Parameters.

\begin{tabular}{|c|c|c|c|c|}
\hline Parameter & Unit & Basecase & Remark & Reference \\
\hline $\mathrm{O}^{\prime} \mathrm{M}^{1}$ & $\%$ & 2.3 & $\%$ TFCI & \\
\hline Indirect expenses ${ }^{2}$ & $\%$ & 4 & $\%$ TFCI & \\
\hline Admin and distribution ${ }^{3}$ & $\%$ & 3 & $\% \mathrm{TFCI}$ & \\
\hline Discount rate ${ }^{4}$ & $\%$ & 10 & Sensitivity $(-50-50 \%)$ & \\
\hline Profit tax & $\%$ & 20 & Sensitivity $(-100-50 \%)$ & \\
\hline Loan interest rate & $\%$ & 4 & & \\
\hline $\begin{array}{l}\text { Feedstock } \\
\text { Utilities }\end{array}$ & $€ /$ dry ton & 50 & Sensitivity $(-30-50 \%)$ & \\
\hline Power & $€ / M W h$ & 40 & Surplus to grid & \\
\hline Process water & $€ / \mathrm{m}^{3}$ & 0.4 & & \\
\hline $\begin{array}{l}\text { Additional biomass to } \mathrm{CHP} \\
\text { Labor }\end{array}$ & $€ / G J$ & 5 & & \\
\hline Staff \& Engineers & $€ /$ fte/a & 75000 & & \\
\hline $\begin{array}{l}\text { Operators } \\
\text { Chemicals }\end{array}$ & $€ /$ fte/a & 55000 & & \\
\hline Sulphuric acid & $€ /$ ton & 100 & & \\
\hline Enzymes & $€ /$ ton & 630 & Sensitivity $(-50-0 \%)$ & [13] \\
\hline $\begin{array}{l}\text { Solvent makeup (ethanol) } \\
\text { Co-products }\end{array}$ & $€ /$ ton & 700 & Sensitivity (25--25\%) & \\
\hline Lignin & $€ /$ dry ton & 630 & Sensitivity $(-50-50 \%)$ & [20] \\
\hline Hemicellulose syrup & $€ /$ ton & 1000 & & \\
\hline
\end{tabular}

1 O\&M cost was estimated assuming maintenance and repair (M\&R) cost of $2 \%$ TFCI and maintenance supplies cost of $15 \% \mathrm{M} \& \mathrm{R} ;{ }^{2}$ Indirect cost include overhead cost ( $60 \%$ of labor plus M\&R), local taxes (1.5\% TFCI) and insurance $(0.7 \% \mathrm{TFCI}){ }^{3}$ Admin and distribution include administrative cost $(25 \%$ overhead) and product distribution and selling ( $5 \%$ of total expenses); ${ }^{4}$ The TFCI is discounted assuming a discount rate of $10 \%$ over a period 20 years.

Table 2. Mass and energy balance.

\begin{tabular}{|c|c|c|c|c|c|c|}
\hline \multirow{3}{*}{$\begin{array}{c}\text { Process Section and Major Streams } \\
\text { Process configuration } \\
\end{array}$} & \multicolumn{3}{|c|}{ Hardwood } & \multicolumn{3}{|c|}{ Softwood } \\
\hline & \multirow[t]{2}{*}{ Input } & \multicolumn{2}{|c|}{ Output } & \multirow[t]{2}{*}{ Input } & \multicolumn{2}{|c|}{ Output } \\
\hline & & HWBF & HWBFX & & SWBF & SWBFX \\
\hline Feedstock and pretreatment & & & & & & \\
\hline $\begin{array}{c}\text { Birchwood, } 6 \% \text { wt. Moisture [kTPY] Birchwood } \\
\text { energy content (MW) }\end{array}$ & $442(275)$ & & & & & \\
\hline $\begin{array}{c}\text { Spruce, } 6 \% \text { wt. Moisture [kTPY] Spruce energy } \\
\text { content (MW) }\end{array}$ & & & & $\begin{array}{l}378 \\
(235)\end{array}$ & & \\
\hline Solvent makeup [kTPY] & 2 & & & 2 & & \\
\hline Steam (3.5 MPa, saturated) [kTPY] & 1965 & & & 1938 & & \\
\hline Catalyst $\left(\mathrm{H}_{2} \mathrm{SO}_{4}\right)[\mathrm{kTPY}]$ & 4 & & & 4 & & \\
\hline $\begin{array}{c}\text { Lignin 38\% wt. Moisture [kTPY] Lignin energy } \\
\text { content (MW) }\end{array}$ & & $81(46)$ & $81(46)$ & & $81(46)$ & $81(46)$ \\
\hline $\begin{array}{l}\text { Hemicellulose syrup, dry wt. [kTPY] } \\
\text { Hemicellulose syrup energy (MW) }\end{array}$ & & & $28(17)$ & & & $22(13)$ \\
\hline Wastewater [kTPY] & & 1743 & 1743 & & 1749 & 1749 \\
\hline SSF [kTPY] & & & & & & \\
\hline Enzymes & 19 & & & 19 & & \\
\hline Lutter water & 673 & & & 609 & & \\
\hline Nutrients & 1.0 & & & 1.0 & & \\
\hline Yeast & 0.5 & & & 0.5 & & \\
\hline $\mathrm{CO}_{2}$ & & 71 & 59 & & 49 & 42 \\
\hline $\begin{array}{l}\text { Product upgrade } \\
\end{array}$ & & & & & & \\
\hline $\begin{array}{c}\text { Ethanol, } 99.5 \% \text { wt. [kTPY] Ethanol energy } \\
\text { content (MW) }\end{array}$ & & $74(69)$ & $61(58)$ & & $51(48)$ & $43(51)$ \\
\hline Lutter water [kTPY] & & 917 & 904 & & 808 & 804 \\
\hline Stillage and organics, dry wt. [kTPY] Stillage & & 222 & 219 & & 213 & 206 \\
\hline energy content (MW) & & $(80.3)$ & (79.8) & & (87.6) & (86.4) \\
\hline Overall efficiency [\%] & & 70 & 73 & & 76 & 78 \\
\hline
\end{tabular}

\section{Results}

Biorefinery concepts for fractionation of woody biomass and its subsequent conversion to ethanol, lignin and hemicellulose syrup was investigated. The process and economic performance of the 
biorefinery concepts were evaluated based on the mass and energy balance derived from the simulation flowsheet developed.

\subsection{Process Performance}

A summary of the major input and output streams for the four process configurations evaluated is presented in Table 2. The valuable product streams were ethanol, organosolv lignin and hemicellulose syrup (for cases with hemicellulose syrup marketing option). The stillage and organics stream combine solid residuals (mostly insoluble lignin) as well as degraded cellulose and hemicellulose derivatives formed during alcohol fermentation such as glycerol, acetic acid, acetaldehydes and so on. The stillage, after filtration and drying, was combusted in the boiler of the CHP system. Alternatively, the stillage and organics stream can be used as substrate for biogas production, see, e.g., Reference [20]. However, the biogas process is not considered in this study. The remaining input streams, such as catalyst, enzymes, nutrients and yeast, have insignificant contribution to the mass balance.

It should be noted that all the biorefinery configurations were tuned to produce 6.34 tons/h dry organosolv lignin to establish a common ground for comparison. The mass balances for the HW and the SW cases required nearly 53 and 45 tons/h of dry feedstock, respectively. The hybrid pretreatment of HW resulted in about $37 \%$ wt. (dry basis) of pretreated solids (pulp) of which $29 \%$ was cellulose, Figure A2. The ethanol yield for HW was about $0.15 \mathrm{~kg} / \mathrm{kg}$ dry feedstock $(76 \%$ of the maximum theoretical ethanol yield assuming total conversion of cellulose to glucose, and a conversion yield of glucose to ethanol of $0.511 \mathrm{~g} / \mathrm{g}$ ). The pulp yield was slightly higher for SW, $43 \% \mathrm{wt}$. of which about $32 \%$ wt. was cellulose, Figure A3. The ethanol yield for SW pulp was $0.123 \mathrm{~kg} / \mathrm{kg}$ dry feedstock ( $58 \%$ of the maximum theoretical ethanol yield). In the scenario in which the hemicellulose syrup was also converted to ethanol (i.e., HWBF and SWBF), the ethanol yield was assumed to be $88 \%$ of the theoretical maximum (i.e., $0.45 \mathrm{~kg} / \mathrm{kg}$ sugar) [23].

To illustrate the energy performance, the energy content of the major streams is also presented in Table 2. The overall efficiency of the biorefinery configurations was in the range $70-78 \%$, lower heating value basis. The conversion efficiency was calculated as the ratio of the energy content of the output material streams (ethanol, organosolv lignin, hemicellulose and solid residuals) to the energy content of the input biomass. The HW cases fall on the lower end of the range because their feedstock requirement was nearly $17 \%$ higher than the SW cases. This deviation derives mainly from the difference in lignin composition of the wood types.

The integrated CHP system provides the hot utility requirements of the biorefinery process. The biorefinery process requires intermediate pressure steam (IPS) at 3-3.5 MPa and low-pressure steam (LPS) at 0.4-0.7 MPa. Under the experimental campaigns, the IPS was directly fed to the hybrid pretreatment reactor which was required to maintain the reactor temperature at $200{ }^{\circ} \mathrm{C}$ and to achieve the target liquid-to-solid ratio (LSR) of the process. In this case, the boiler must be continuously supplied with the same amount of makeup feedwater. Alternatively, when the premixed solvent and woodchips was indirectly heated using IPS, the IPS consumption of the pretreatment process would reduce to about one-third of the steam that would have been needed when all the water required to achieve the target LSR was added in the form steam. The latter option was assumed for evaluating the full-scale biorefinery concepts investigated here. The LPS supplies the thermal requirements to recover organosolv solvent, to concentrate hemicellulose sugars and to boil-up the bottoms of the distillation rectification and entrainer regeneration columns. The boiler of the CHP system generates all steam at the maximum cycle pressure and temperature, 120 barg and $520^{\circ} \mathrm{C}$. The back-pressure steam turbine distributes the steam to the biorefinery processes at the desired pressure levels, $0.4-3 \mathrm{MPa}$, while exploiting the exergy of the HPS to drive an electric generator. The CHP system produce nearly $18 \mathrm{MW}$ and $16 \mathrm{MW}$ net surplus power for the HW and SW cases, respectively. 


\subsection{Economic Performance}

The equipment cost for the biorefinery concepts including the integrated CHP system account for nearly $245 \mathrm{M} €$ for hardwood and $223 \mathrm{M} €$ for softwood, about $6 \%$ lower due difference in feedstock composition. Figure 2 shows the TFCI categorized by major process sections. The TFCI per annual ethanol production was calculated to be in the range $2-4.5 € / \mathrm{L}$, well in line with the range reported by Kautto et al. [9]. To maintain the same lignin productivity nearly $17 \%$ lower softwood feedstock was needed. Under the assumed economic conditions presented in Table 2, the economic assessment of the biorefinery concepts resulted in net present values (NPVs) ranging from -198 M€ to $15 \mathrm{M} €$. Only the HWBFX case resulted in positive NPV. The main contributors to the cost build-up were the capital investment, feedstock, utilities and chemicals. Nearly $40 \%$ of the estimated TFCI derives from the CHP system that supplies the hot utility and electricity requirements of the biorefinery concepts.

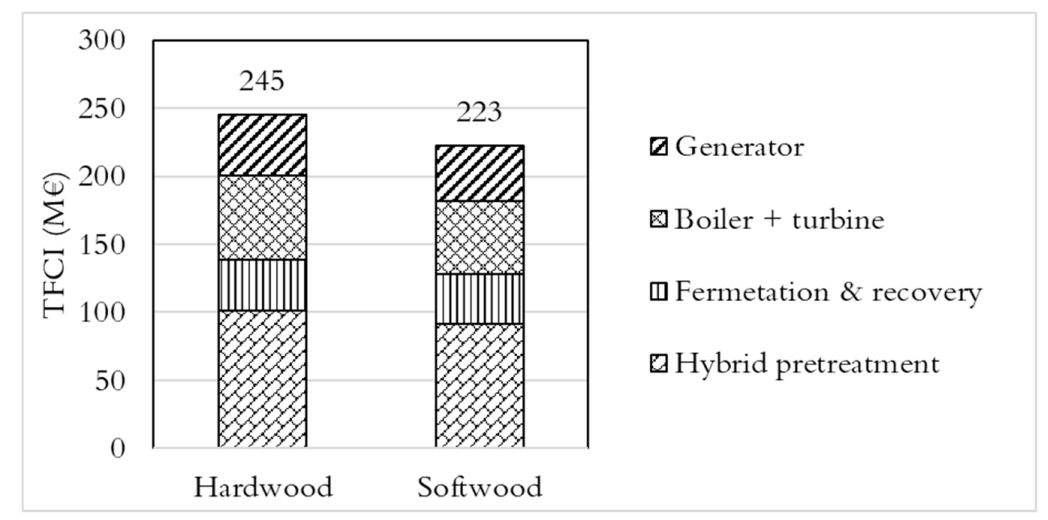

Figure 2. TFCI for hardwood and softwood categorized by process section.

\subsubsection{Production Cost}

The investigated cases revealed the hybrid pretreatment process can enable economically feasible biorefinery concepts that effectively fractionate woody biomass into cellulose-rich pulp, lignin and hemicellulose sugars. Figure 3 presents the cost build-up, income generated from co-product sales and the MESP required to achieve zero NPV. For the basecase operation of the biorefinery concepts, i.e., the economic parameters in Table 2 and assuming a straight-line discounting, the MESP was calculated to be in the range of $0.53-0.95 € / L$. It should be noted that the MESP was calculated by allocating all cost to ethanol only, i.e., the revenue from the co-products was subtracted from the total cost according to their market values and the remainder was assigned to ethanol. The low-end of the range corresponds to hardwood case with hemicellulose syrup marketing option, whereas the high-end corresponds to the softwood without hemicellulose syrup case. Compared to the reference price of ethanol, $0.55 € / \mathrm{L}(700 € / \mathrm{t})$, a premium of $171 \%$ would be required for the worst performing configuration to breakeven.

Capital recovery, utilities and chemicals, and feedstock categories were the major contributors to the cost build contributing about $26 \%, 22 \%$ and $20 \%$ of the total expenses, respectively. The capital recovery is strongly linked to utilities and would drop considerably with reduced steam usage or lowered LSR in the hybrid pretreatment reactor. Localizing the biorefinery next to an existing CHP system or at a sawmill site with an integrated boiler would be beneficial to reduce the capital investment. In the best-case scenario the capital investment can reduce by over one-third when the hosting site has an existing boiler with enough unused capacity to cover the steam demand of the pretreatment process. However, given the extent of steam required to maintain the operational temperature of pretreatment reactor, to cover it entirely from unused capacity of existing boilers is highly unlikely. Therefore, some form of capacity expansion is inevitable even with integrated design options. In case of integration at a sawmill site, where the feedstock can be sourced onsite, the cost of feedstock reduces due to the avoided cost of 
transportation and logistics leading to improved economic performance of the biorefinery concepts, e.g., Reference [24].

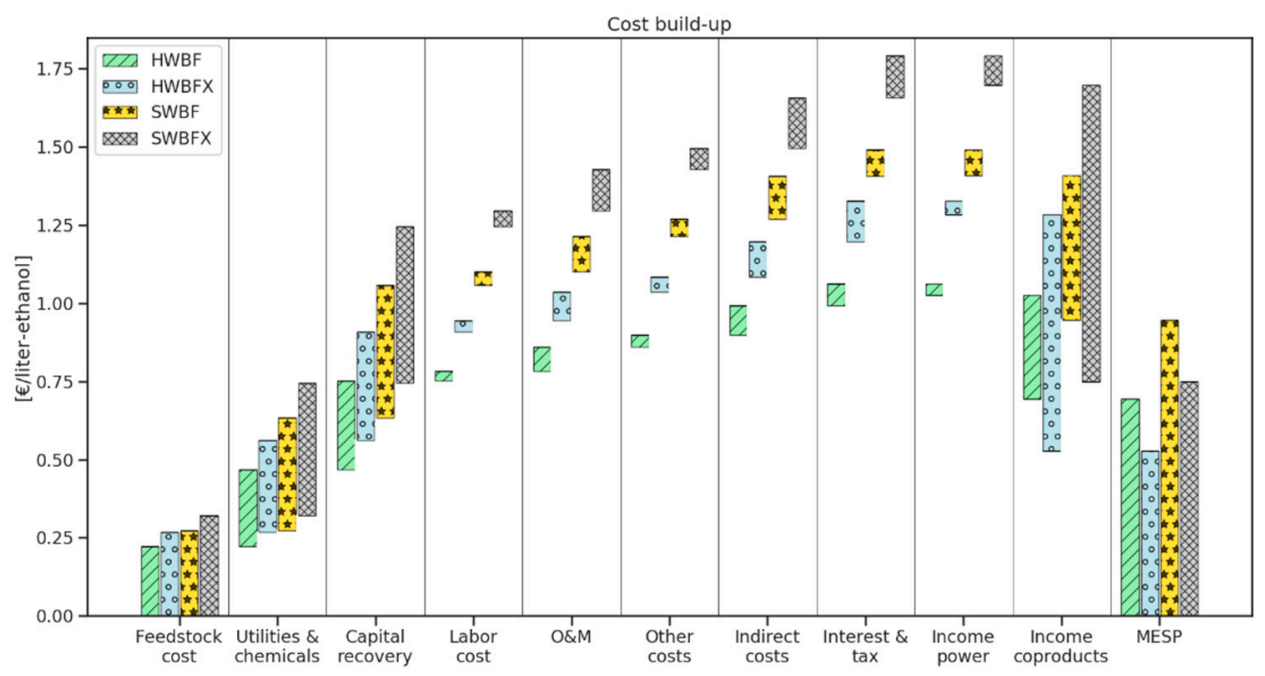

Figure 3. Cost build-up, co-product revenue and the MESP required-all costs allocated to ethanol.

The category for utilities and chemicals was the second most contributor to the cost build-up, largely driven by the cost of the biomass fuel fired in the boiler. The steam generation is directly related to the high LSR, 10 in this case, which required large amount of pre-heating steam nearly $2 \mathrm{~kg} / \mathrm{kg}$ dry wood. The next largest contributor in this category is the cost of saccharification enzymes which has loading rate of nearly $125 \mathrm{~g} / \mathrm{kg}$ pretreated solids (dry pulp) under a full-scale optimal operation, which translated to nearly $2500 \mathrm{~kg} / \mathrm{h}$ for the capacity of the biorefinery plants investigated. This needs close attention and optimization to achieve reasonable rates that can improve the process economics.

Feedstock cost was the third largest contributor to the cost build-up generating about $20 \%$ of the expenses. Since a significant part of hemicellulose was degraded during the process and the degradation products were not recovered from the hemicellulose stream [8,18], this affected the overall resource efficiency and as such made the impact of the feedstock price higher. It is worth mentioning that during the current study the hemicellulose degradation products such as furfural were not considered as a marketable product. Optimizing the process to minimize degradation of hemicellulosic sugars, or inclusion of furfural in the product portfolio would improve product yield and the overall process economy.

\subsubsection{Sensitivity Analysis}

A sensitivity analysis was performed to address the most influential technical, economic and market-related uncertainties. The technical uncertainties are strongly linked to the scaling of the different process units, from pilot to commercial capacity, in terms of chemicals and utility consumptions. For instance, reduced enzyme loading would be expected for a full-scale commercial installation than what have been used in the model. Likewise, linear scaling of steam use in the pretreatment process would overestimate the capacity of integrated CHP system and, thus, the total TFCI. The economic uncertainties were mainly linked to the assumed discount rate, profit tax and investment, whereas the market uncertainties were linked to feedstock price, lignin value and ethanol market price. The sensitivity of MESP towards variation on the values of these factors is presented in Figure 4. Each of the technical, economic or market variable was varied one at a time while the remaining variables were kept the same as the basecase value (Table 1). 

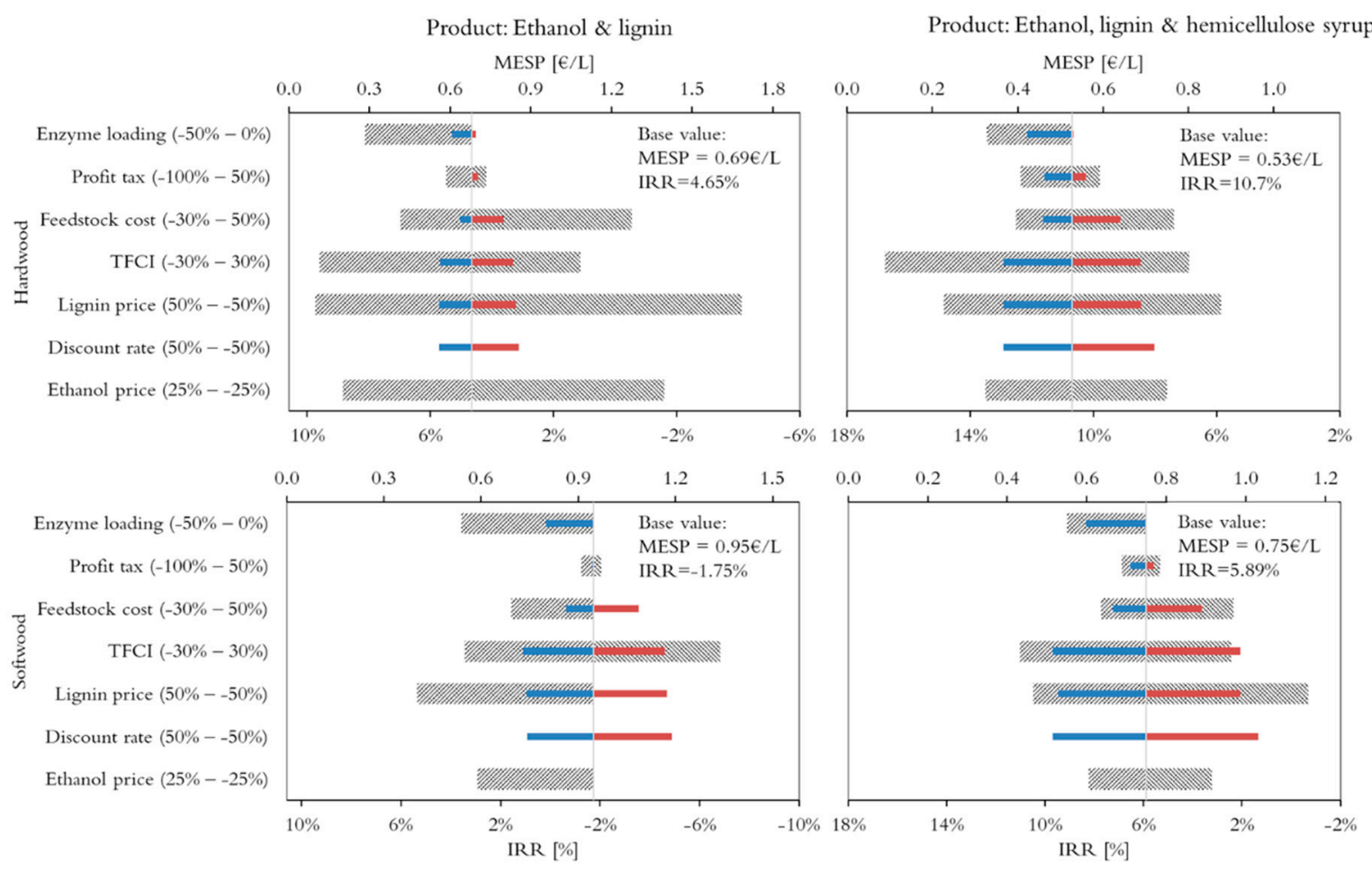

Figure 4. Tornado diagrams for single parameter sensitivity analysis of MESP (solid bars-top axis) and IRR (patterned bars-bottom axis).

Due to expected uncertainties on the capital investment estimates and the assumed discount rate, effect of variation in the TFCI from $-30 \%$ to $30 \%$ and that of the discount rate from $-50 \%$ to $50 \%$ were applied to investigate the sensitivity of MESP. In addition, the impact of lignin price and feedstock cost considering variation from $-50 \%$ to $50 \%$ and from $-30 \%$ to $50 \%$, respectively. The impact of market price of ethanol on the IRR of the project was investigated as well.

The MESP showed high sensitivity to uncertainties in capital investment and discount rates and to a lesser degree to variations in feedstock cost and lignin price. Previous studies, e.g., References $[9,10,20,25]$, have shown that the TFCI and discount rates lean towards the favorable end of the range considered in the sensitivity investigations (Figure 4). For woody biomass feedstock, the price $50 € /$ ton dry is rather low unless the biorefinery is located near or integrated at a forest industry site where the woodchips or sawdust can be acquired onsite avoiding logistics and transportation expenses. Otherwise, the feedstock price must be augmented with logistics and transportation cost which typically adds about $30-50 \%$ of the assumed price depending on the transportation distance, $100-500 \mathrm{~km}$ [26]. Therefore, for standalone installations the feedstock price inclines towards the unfavorable end of the range used for sensitivity analysis.

\section{Discussion}

Organosolv pulping, often discussed as an alternative process to conventional chemical pulping process, has not been the favored pulping process due to high production cost. The cost of recovering the organic solvent and low pulp yield—for example relative to kraft pulping-being the main drivers. Compared to conventional chemical pulping processes, for the capacity of the biorefinery plants investigated, the steam consumption to recover the solvent adds equivalent to about $15-20 \%$ of the amount steam required for the hybrid pretreatment reactor or alternatively consumes 7-9 MWel in case MVR evaporator was used to recover the solvent. In contrast, the chemicals recovery process of kraft pulping produce steam when the pulping byproduct black liquor is combusted to recover the cooking chemicals. This holds true even for kraft mills with the option of lignin extraction, e.g., via lignoboost process, in which case part of the lignin enough to allow black liquor combustion 
in recovery boiler is left in the stream $[27,28]$. On the positive side, the organosolv lignin has quality advantage over kraft lignin which contains impurities derived from the pulping chemicals, such as sulphur. With growing interest in high-quality lignin, the hybrid pretreatment process is likely to become an attractive option. When markets that appreciate sulphur- and odor-free lignin are in place, chemical pulp mills may reconsider their position towards organosolv processes.

Degradation of hemicellulose was identified as one of the major sources of inefficiencies that limited the yield of the hybrid pretreatment process. The harsh conditions of the pretreatment reactor, rather tuned to favor pulp yield, stimulated excessive degradation to the hemicellulose fraction of the feedstock hampering the yield hemicellulose sugars. The economic evaluations have shown the cases with hemicellulose sugars marketing option performed better than those with hemicellulose sugars fermentation to ethanol option, highlighting the importance of minimizing degradation of hemicellulosic derivates in the pretreatment reactor. Therefore, devising methods that enable the recovery of hemicellulosic fractions early during the pretreatment process would contribute a great measure to the realization of profitable biorefinery concepts employing the service of the hybrid pretreatment technique. Alternatively, the performance of the process towards hemicellulose fraction can be improved by integrating value chains that valorize the degraded hemicellulosic derivatives to marketable products such as furfural and acetic acid. However, these value chains were not investigated here.

Ethanol was targeted as final product given the investigative nature of the study. Nonetheless, Figure 3 shows that the combined earnings from lignin and hemicellulose syrup contributed more than ethanol sales. This indicates targeting high value products would improve process economics. Lignin, being the second major product of the biorefinery, generated significant part of the income. The lignin market, currently under development phase, is expected to grow fast depending on the intended application area. For example, applications as binding agent or thermoplastics would favor lignin prices towards the high-end of the range used in the sensitivity analysis. Moreover, hydrogenolytic depolymerization of lignin is an active research area pursued by many researchers and institutions in the context of value-added biochemicals and biofuels, e.g., References [16,29-31].

Under the experimental campaigns, the hybrid pretreatment process was characterized by high LSR which rendered the full-scale process energy intensive as all the water added to the pretreatment reactor was in the form saturated steam at pressure of $3 \mathrm{MPa}$. Future developments must target to reduce the LSR well below the experimental value to achieve improved process performance in terms of energy and water usage. To further minimize process water consumption, the water required for saccharification step can be sourced from the lutter water after ethanol purification process or elsewhere in the process. For a commercial scale installation, all or part of the thermal energy required to maintain the hybrid pretreatment process at the desired reactor temperature may be satisfied using external heat source instead of directly supplying steam to the reactor as was the case for the experimental campaigns. This can be achieved via heat exchangers designed to preheat the organosolv solvent to a desired temperature level and by maintaining the external walls of the reactor insulated to minimize heat losses.

To illustrate on the performance of integrated process configurations, Pinch Analysis [32] was applied to the biorefinery concepts and a split grand composite curve for the HW case is shown in Figure 5 as a representative. The so-called integrated grand composite curve takes into account the major process streams that require heating or cooling including that of the CHP system, see, e.g., References [33-35]. Minimum temperature difference was applied to each stream according to its heat transfer nature, i.e., $20^{\circ} \mathrm{C}$ for combustion products and $4{ }^{\circ} \mathrm{C}$ for steam and aqueous streams. The red composite curve derives from the biorefinery process streams and the combustion streams of the CHP system. The lower profile of the red composite curve below $290{ }^{\circ} \mathrm{C}$ originates from the streams of the bioethanol process; whereas the upper profile represents the thermal energy of the combustion products which is split between radiative (at $850{ }^{\circ} \mathrm{C}$ ) and convective $\left(850-150{ }^{\circ} \mathrm{C}\right.$ ) 
heat transfer segments. The blue composite curve shows the steam Rankine cycle streams, in which the upper part represents generation of the HPS (superheating, evaporation and part of feedwater preheating segments) and the low part for condensation of process HPS (regeneration column reboiler), IPS (pretreatment and rectification column reboiler) and LPS (pretreatment, beer and distillation columns reboilers). As depicted in Figure 5, the thermal loads for ethanol recovery and upgrading take place at constant temperatures which are conveniently satisfied using condensing steam extracted from the back-pressure turbine. The heat demand of the pretreatment reactor also spans between $85^{\circ} \mathrm{C}$ and slightly over $200^{\circ} \mathrm{C}$, requiring saturated steam both at $0.4 \mathrm{MPa}$ (for the low temperature segment) and $3 \mathrm{MPa}$ (for the high-temperature part). In addition, Figure 5 illustrates graphically how well the steam system exploits the heat pocket created by the hot combustion and biorefinery streams while providing information on amount and pressure levels of the steam used by the bioethanol process. It is worth mentioning that the gap between the ordinate axis and left-end of the blue curve at $0.4 \mathrm{MPa}$ represents the net power production of the CHP system.

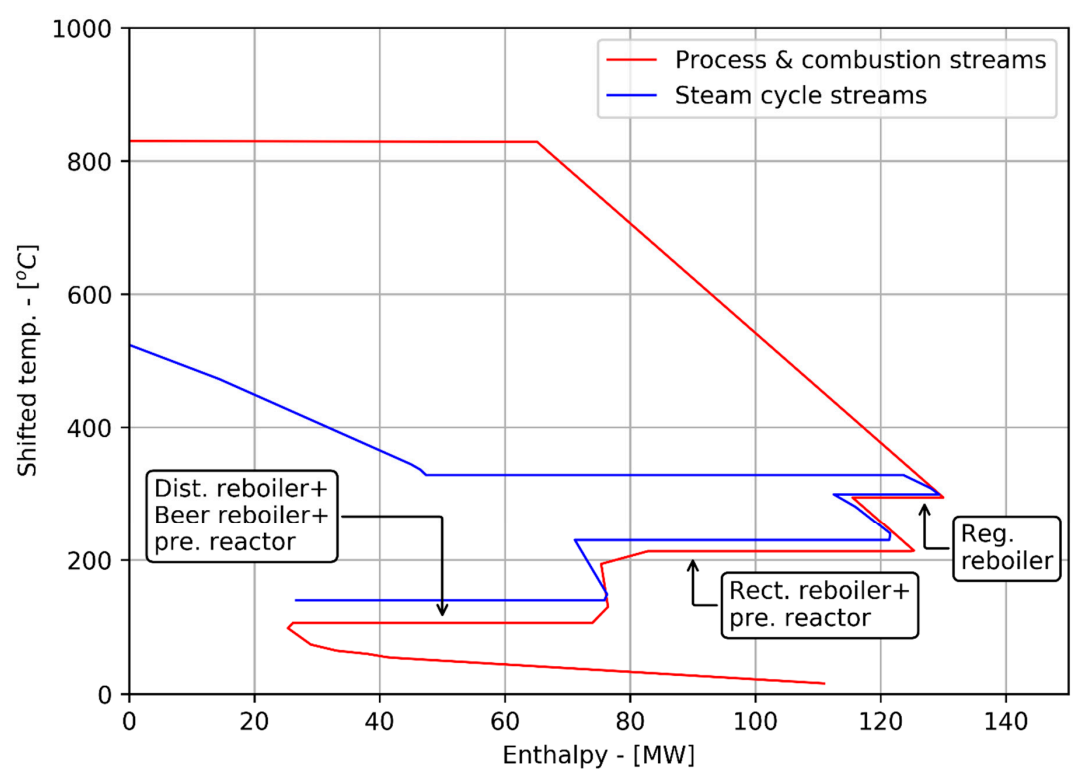

Figure 5. Split grand composite curve of the biorefinery concept for HW case.

\section{Concluding Remarks}

Hardwood and softwood chips based biorefinery concepts producing ethanol $(0.12-0.15 \mathrm{t})$, lignin $(0.12 \mathrm{t})$ and sugars $(0.06-0.07 \mathrm{t}$; mainly from hemicellulose) per ton of dry woodchips with an overall energy efficiency of $70-78 \%$ were investigated. The biorefinery concepts were derived from a full-scale simulation model that was developed based on lab scale experimental data. Under the assumed economic condition, the biorefinery concepts resulted in net present value ranging from -198 to $15 \mathrm{M€}$ and the corresponding IRR in the range $-1.75-10.7 \%$. However, the sensitivity analysis with projected values of key technical and economic parameters showed potential for profitability, resulting in IRR as high as $17 \%$ for HWBFX case.

The hybrid organosolv-steam explosion pretreatment is an energy intensive process requiring significant amounts of IPS that adversely affected the process economy. Integration of the biorefinery with an existing CHP system or a sawmill with a boiler could improve its economic performance. Besides, degradation of hemicellulosic sugar derivatives during the pretreatment stage reduced the hemicellulose sugars yield, which negatively affected the economic performance. Therefore, a great deal more effort should be made to improve steam consumption and minimize hemicellulose degradation during the pretreatment process. 
Author Contributions: L.M., U.R. and P.C. developed the hybrid process concept and conducted the experimental campaigns that were used as basis for the technoeconomic assessment. S.M. developed the technoeconomic model and drafted the manuscript. All authors have read, corrected and approved the manuscript.

Funding: This research was funded by Swedish Energy Agency (SolveFuels project), grant number 2015-006989.

Acknowledgments: Authors would like to thank Bio4Energy, a strategic research environment appointed by the Swedish government, for supporting this work.

Conflicts of Interest: The authors declare no conflicts of interest.

\section{Abbreviations}

$\begin{array}{ll}\text { CEPCI } & \text { chemical engineering plant cost index } \\ \text { CHP } & \text { combined heat and power } \\ \text { fte } & \text { full time equivalent } \\ \text { HPS } & \text { high-pressure steam } \\ \text { HW } & \text { hardwood } \\ \text { IPS } & \text { intermediate pressure steam } \\ \text { IRR } & \text { internal rate of return } \\ \text { ISBL } & \text { inside battery limit } \\ \text { LPS } & \text { low-pressure steam } \\ \text { LSR } & \text { liquid-to-solid ratio } \\ \text { MESP } & \text { minimum ethanol selling price } \\ \text { MVR } & \text { mechanical vapor recompression } \\ \text { NPV } & \text { net present value } \\ \text { OSBL } & \text { outside battery limit } \\ \text { PEC } & \text { purchased equipment cost } \\ \text { SW } & \text { softwood } \\ \text { TFCI } & \text { total fixed capital investment }\end{array}$




\section{Appendix A Process Flowsheet}

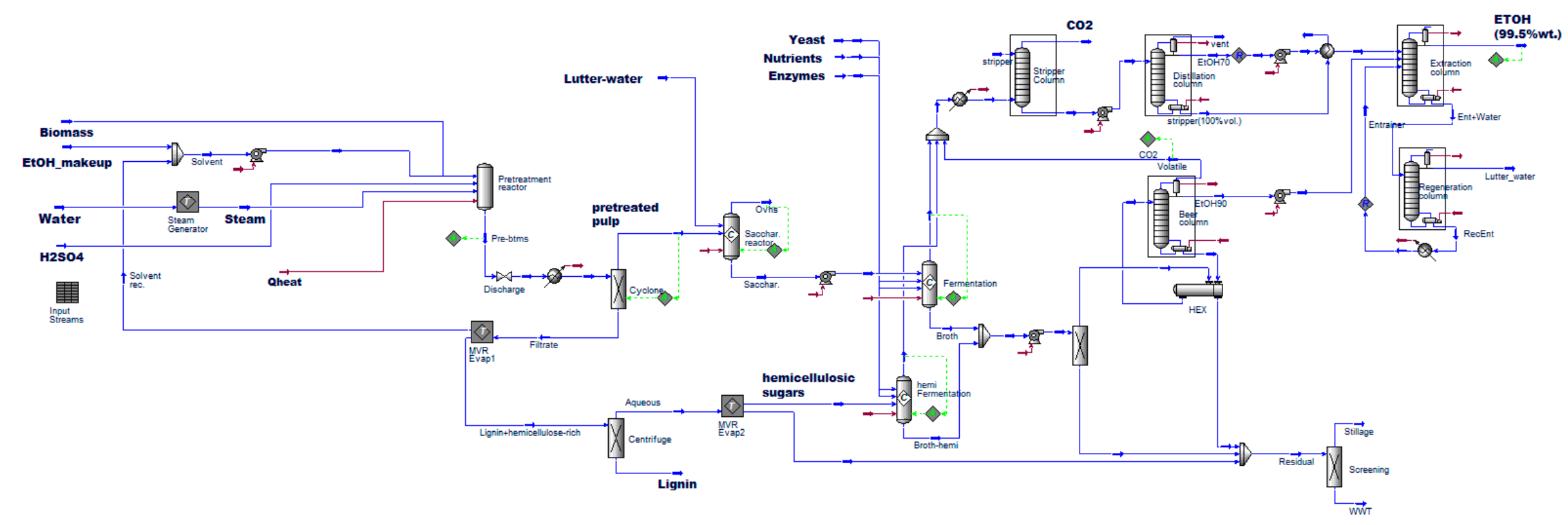

Figure A1. Simulation model of the conceptual process. 


\section{Appendix B Fractionation Stream Composition and Normalized Yield}

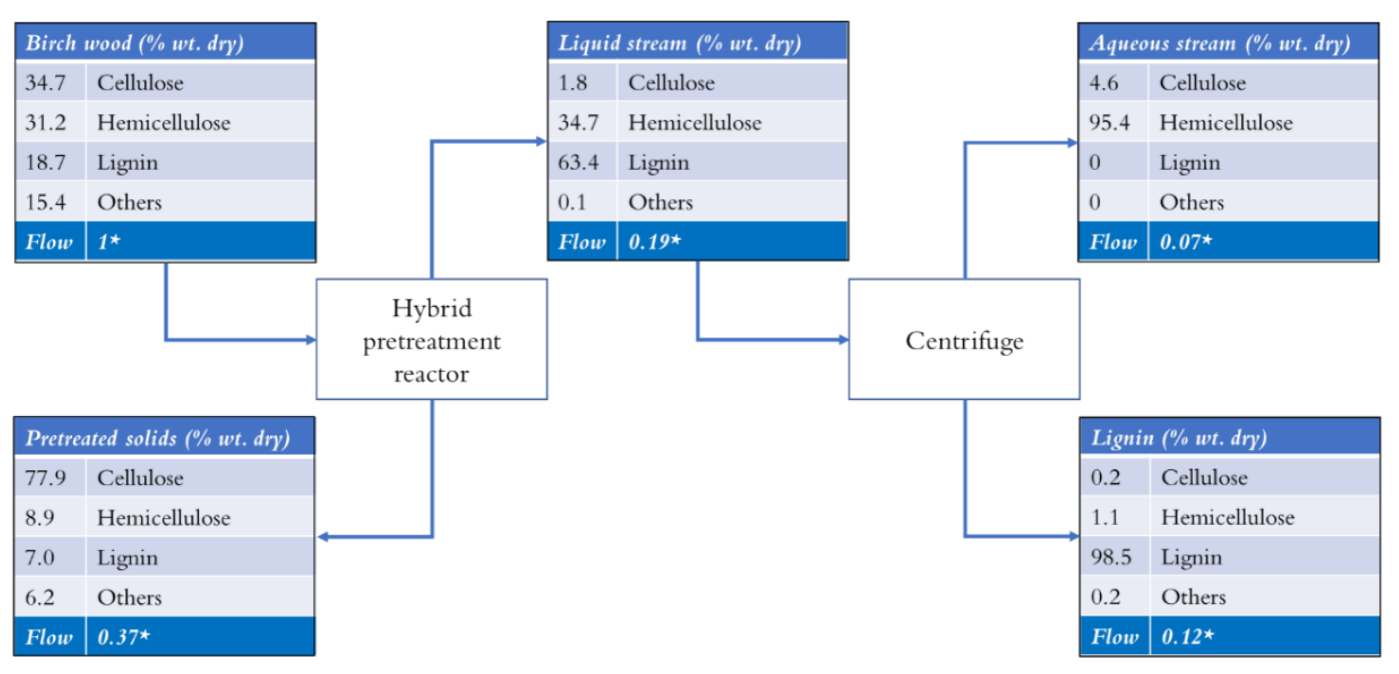

^ Flow normalized to feedstock input (dry basis)

Figure A2. Stream composition of hybrid organosolv-steam explosion pretreatment of HW.

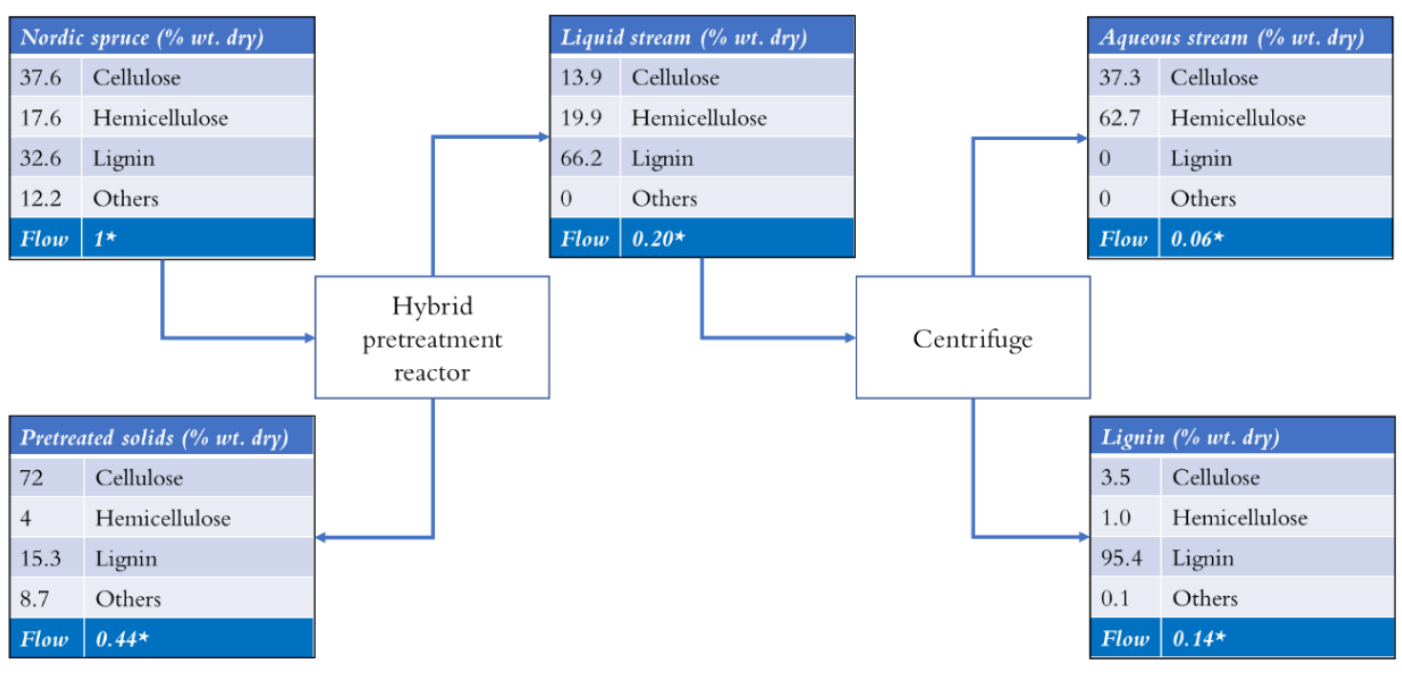

^ Flow normalized to feedstock input (dry basis)

Figure A3. Stream composition of hybrid organosolv-steam explosion pretreatment of SW.

\section{References}

1. Gassner, M.; Maréchal, F. Thermo-economic process model for thermochemical production of Synthetic Natural Gas (SNG) from lignocellulosic biomass. Biomass Bioenergy 2009, 33, 1587-1604. [CrossRef]

2. Rauch, R.; Hrbek, J.; Hofbauer, H. Biomass gasification for synthesis gas production and applications of the syngas. Wiley Interdiscip. Rev. Energy Environ. 2014, 3, 343-362. [CrossRef]

3. Jones, S.; Valkenburg, C.; Walton, C. Production of Gasoline and Diesel from Biomass via Fast Pyrolysis, Hydrotreating and Hydrocracking: A Design Case; Pacific Northwest National Lab. (PNNL): Richland, WA, USA, 2009.

4. Zheng, A.; Jiang, L.; Zhao, Z.; Huang, Z.; Zhao, K.; Wei, G.; Li, H. Catalytic fast pyrolysis of lignocellulosic biomass for aromatic production: Chemistry, catalyst and process. Wiley Interdiscip. Rev. Energy Environ. 2017, 6, e234. [CrossRef]

5. Li, W.; Dang, Q.; Smith, R.; Brown, R.C.; Wright, M.M. Techno-economic analysis of the stabilization of bio-oil fractions for insertion into petroleum refineries. ACS Sustain. Chem. Eng. 2017, 5, 1528-1537. [CrossRef] 
6. Marker, T.L.; Felix, L.G.; Linck, M.B.; Roberts, M.J.; Ortiz-Toral, P.; Wangerow, J. Integrated hydropyrolysis and hydroconversion $\left(\mathrm{IH} 2{ }^{\circledR}\right)$ for the direct production of gasoline and diesel fuels or blending components from biomass, Part 2: Continuous testing. Environ. Prog. Sustain. Energy 2014, 33, 762-768. [CrossRef]

7. Zhu, Y.; Biddy, M.J.; Jones, S.B.; Elliott, D.C.; Schmidt, A.J. Techno-economic analysis of liquid fuel production from woody biomass via hydrothermal liquefaction (HTL) and upgrading. Appl. Energy 2014, 129, 384-394. [CrossRef]

8. Matsakas, L.; Raghavendran, V.; Yakimenko, O.; Persson, G.; Olsson, E.; Rova, U.; Olsson, L.; Christakopoulos, P. Lignin-first biomass fractionation using a hybrid organosolv-Steam explosion pretreatment technology improves the saccharification and fermentability of spruce biomass. Bioresour. Technol. 2019, 273, 521-528. [CrossRef]

9. Kautto, J.; Realff, M.J.; Ragauskas, A.J.; Kässi, T. Economic analysis of an organosolv process for bioethanol production. BioResources 2014, 9, 6041-6072. [CrossRef]

10. da Silva, A.R.G.; Torres Ortega, C.E.; Rong, B.G. Techno-economic analysis of different pretreatment processes for lignocellulosic-based bioethanol production. Bioresour. Technol. 2016, 218, 561-570. [CrossRef] [PubMed]

11. Nitsos, C.; Rova, U.; Christakopoulos, P. Organosolv Fractionation of Softwood Biomass for Biofuel and Biorefinery Applications. Energies 2017, 11, 50. [CrossRef]

12. Frankó, B.; Galbe, M.; Wallberg, O. Bioethanol production from forestry residues: A comparative techno-economic analysis. Appl. Energy 2016, 184, 727-736. [CrossRef]

13. Ruiz, E.; Castro, E.; Cardona-Alzate, C.A.; Solarte-Toro, J.C.; Romero-García, J.M.; Susmozas, A. Techno-economic feasibility of bioethanol production via biorefinery of olive tree prunings (OTP): Optimization of the pretreatment stage. Holzforschung 2018, 73, 3-13. [CrossRef]

14. Mohammad, B.T.; Al-shannag, M.; Alnaief, M. Production of Multiple Biofuels from Whole Camelina Material: A Renewable Energy Crop. BioResources 2018, 13, 4870-4883. [CrossRef]

15. Evstigneyev, E.I. Selective Depolymerization of Lignin: Assessment of Yields of Monomeric Products. J. Wood Chem. Technol. 2018, 38, 409-415. [CrossRef]

16. Sun, Z.; Fridrich, B.; de Santi, A.; Elangovan, S.; Barta, K. Bright Side of Lignin Depolymerization: Toward New Platform Chemicals. Chem. Rev. 2018, 118, 614-678. [CrossRef]

17. Funkenbusch, L.L.T.; Mullins, M.E.; Vamling, L.; Belkhieri, T.; Srettiwat, N.; Winjobi, O.; Shonnard, D.R.; Rogers, T.N. Technoeconomic assessment of hydrothermal liquefaction oil from lignin with catalytic upgrading for renewable fuel and chemical production. Wiley Interdiscip. Rev. Energy Environ. 2019, 8, e319. [CrossRef]

18. Matsakas, L.; Nitsos, C.; Raghavendran, V.; Yakimenko, O.; Persson, G.; Olsson, E.; Rova, U.; Olsson, L.; Christakopoulos, P. A novel hybrid organosolv: Steam explosion method for the efficient fractionation and pretreatment of birch biomass. Biotechnol. Biofuels 2018, 11, 160. [CrossRef]

19. Branco, R.H.R.; Serafim, L.S.; Xavier, A.M.R.B. Second generation bioethanol production: On the use of pulp and paper industry wastes as feedstock. Fermentation 2019, 5, 4. [CrossRef]

20. Nitzsche, R.; Budzinski, M.; Gröngröft, A. Techno-economic assessment of a wood-based biorefinery concept for the production of polymer-grade ethylene, organosolv lignin and fuel. Bioresour. Technol. 2016, 200, 928-939. [CrossRef]

21. Sinnott, R.; Towler, G. Chemical Engineering Design-Principles, Practice and Economics of Plant and Process Design; Elsevier: Amsterdam, The Netherlands, 2008; ISBN 9780080966595.

22. Woods, D.R. Rules of Thumb in Engineering Practice; Wiley: Weinheim, Germany, 2007; ISBN 9783527312207.

23. Chandrakant, P.; Bisaria, V.S. Simultaneous bioconversion of cellulose and hemicellulose to ethanol. Crit. Rev. Biotechnol. 1998, 18, 295-331. [CrossRef]

24. Mesfun, S.; Anderson, J.-O.; Umeki, K.; Toffolo, A. Integrated SNG Production in a Typical Nordic Sawmill. Energies 2016, 9, 333. [CrossRef]

25. Galbe, M.; Zacchi, G. A review of the production of ethanol from softwood. Appl. Microbiol. Biotechnol. 2002, 59, 618-628. [CrossRef] [PubMed]

26. Searcy, E.; Flynn, P.; Ghafoori, E.; Kumar, A. The relative cost of biomass energy transport. Appl. Biochem. Biotechnol. 2007, 137, 639-652. [CrossRef] [PubMed]

27. Mesfun, S.; Lundgren, J.; Grip, C.-E.; Toffolo, A.; Nilsson, R.L.K.; Rova, U. Black liquor fractionation for biofuels production-A techno-economic assessment. Bioresour. Technol. 2014, 166, 508-517. [CrossRef] [PubMed] 
28. Vakkilainen, E.; Välimäki, E. Effect of Lignin Separation to Black Liquor and Recovery Boiler Operation. TAPPI Eng. Pulping Environ. Conf. 2009, 18. [CrossRef]

29. Kärkäs, M.D. Lignin Hydrogenolysis: Improving Lignin Disassembly through Formaldehyde Stabilization. ChemSusChem 2017, 10, 2111-2115. [CrossRef]

30. Wang, Q.; Guan, S.; Shen, D. Experimental and Kinetic Study on Lignin Depolymerization in Water/Formic Acid System. Int. J. Mol. Sci. 2017, 18, 2082. [CrossRef]

31. Guadix-Montero, S.; Sankar, M. Review on Catalytic Cleavage of C-C Inter-unit Linkages in Lignin Model Compounds: Towards Lignin Depolymerisation. Top. Catal. 2018, 61, 183-198. [CrossRef]

32. Kemp, C.-I. Pinch Analysis and Process Integration: A User Guide on Process Integration for the Efficient Use of Energy, 2nd ed.; Butterworth-Heinemann Ltd.: Oxford, UK, 2007; ISBN 0750682604.

33. Mesfun, S.; Lundgren, J.; Toffolo, A.; Lindbergh, G.; Lagergren, C.; Engvall, K. Integration of an Electrolysis Unit for Producer Gas Conditioning in a Bio-Synthetic Natural Gas Plant. J. Energy Resour. Technol. 2018, 141, 012002. [CrossRef]

34. Mesfun, S.; Toffolo, A. Integrating the processes of a Kraft pulp and paper mill and its supply chain. Energy Convers. Manag. 2015, 103, 300-310. [CrossRef]

35. Morandin, M.; Toffolo, A.; Lazzaretto, A.; Maréchal, F.; Ensinas, A.V.; Nebra, S.A. Synthesis and parameter optimization of a combined sugar and ethanol production process integrated with a CHP system. Energy 2011, 36, 3675-3690. [CrossRef]

(C) 2019 by the authors. Licensee MDPI, Basel, Switzerland. This article is an open access article distributed under the terms and conditions of the Creative Commons Attribution (CC BY) license (http://creativecommons.org/licenses/by/4.0/). 